\title{
Kirramyces viscidus sp. nov., a new eucalypt pathogen from tropical Australia closely related to the serious leaf pathogen, Kirramyces destructans
}

\author{
V. Andjic A , P. A. Barber ${ }^{\mathrm{A}}$, A. J. Carnegie ${ }^{\mathrm{B}}$, G. S. Pegg C, G. E. St. J. Hardy ${ }^{\mathrm{A}, \mathrm{E}}$, \\ M. J. Wingfield ${ }^{\mathrm{D}}$ and T. I. Burgess ${ }^{\mathrm{A}, \mathrm{D}}$ \\ ABiological Science, Murdoch University, South Street, Murdoch, WA 6150, Australia. \\ ${ }^{B}$ Forest Resources Research, NSW Department of Primary Industries, PO Box 100, Beecroft, NSW 2119 , Australia. \\ ${ }^{\mathrm{C}}$ Department of Primary Industries and Fisheries, Horticulture and Forestry Science, Indooroopilly, QId 4068, \\ Australia. \\ DForestry and Agricultural Biotechnology Institute (FABI), University of Pretoria, Pretoria 0002, South Africa. \\ ${ }^{\mathrm{E} C}$ Corresponding author. Email: g-hardy@murdoch.edu.au
}

\begin{abstract}
Kirramyces destructans is a serious pathogen causing a leaf, bud and shoot blight disease of Eucalyptus plantations in the subtropics and tropics of South-East Asia. During surveillance of eucalypt taxa trials in northern Queensland, symptoms resembling those of $K$. destructans were observed on Eucalyptus grandis and E. grandis $\times$ E. camaldulensis. Phylogenetic and morphological studies revealed that the Kirramyces sp. associated with these symptoms represents a new taxon described here as $K$. viscidus sp. nov., which is closely related to K. destructans. Plantation assessments revealed that while E. grandis from the Copperload provenance, collected in northern Queensland, recovered from disease, E. grandis $\times$ E. camaldulensis hybrids from South America were highly susceptible to infection by $K$. viscidus and are not recommended for planting in northern Queensland. Preliminary results suggest the fungus probably originates from Australia. K. viscidus is closely related to $K$. destructans and causes a disease with similar symptoms, suggesting that it could seriously damage Australian eucalypt plantations, especially those planted off-site.
\end{abstract}

Additional keywords: phylogenetics.

\section{Introduction}

The eucalypt plantation industry in Australia is relatively new, with major expansion from $\sim 200000$ to 600000 ha occurring only in the last 10 years (National Forestry Inventory 2004). These plantations are predominantly of Eucalyptus globulus, situated in southern Australia and the major end-use is paper and pulp. A comparatively small eucalypt plantation industry for both timber and pulpwood is developing in the subtropical regions of northern New South Wales (NSW) and southern Queensland (Qld) and expanding into the tropical regions of northern Qld (Dickinson et al. 2004; Carnegie et al. 2005). The majority of these plantations are established on previous agricultural land and do not involve the clearing of native vegetation.

Eucalypt species trials have been established throughout Australia to test the suitability of different environments for growing eucalypts. Some of these trials have been planted in the east coast tropics in a region referred to as Far North Queensland (FNQ) (Dickinson et al. 2004; Lee 2007), where the climate is similar to parts of South-East Asia. The eucalypt species being tested in these trials include $E$. grandis, E. camaldulensis and hybrids between these two species, which are commonly used in tropical plantation forestry worldwide (Turnbull 2000).

Several eucalypt diseases have emerged in South-East Asia that are unknown in Australia (Wingfield et al. 1996b; Barber 2004; Burgess et al. 2006). These diseases threaten the biosecurity of Australia's eucalypts. Under an existing project, eucalypt taxa trials in northern Australia are currently being monitored for incursions of pathogens from Australia's northern neighbours such as Indonesia and Papua New Guinea (T. I. Burgess, pers. comm.).

Kirramyces J. Walker et al. species are anamorphs of Mycosphaerella Johanson. Species such as $K$. zuluensis (M.J. Wingf., Crous \& T.A. Cout.) Andjic \& M.J. Wingf., $K$. destructans (M.J. Wingf. \& Crous), K. eucalypti (Cooke \& Massee) J. Walker, B. Sutton \& Pascoe and $K$. epicoccoides (Cooke \& Massee) J. Walker, B. Sutton \& Pascoe, are common and important pathogens of eucalypts (Wingfield et al. 1996a; Park et al. 2000; Carnegie 2007b). K. zuluensis and $K$. destructans are unknown in Australia. K. zuluensis causes a serious stem canker disease on Eucalyptus species in subtropical areas of South Africa (Wingfield et al. 1996a), Hawaii (Cortinas et al. 2004), Ethiopia and Uganda (Gezahgne et al. 2005), 
Argentina and Vietnam (Gezahgne et al. 2003), China (Cortinas et al. 2006) and Uruguay (M. J. Wingfield, unpubl. data). $K$. destructans is an aggressive, destructive pathogen causing distortion of infected leaves and blight of young leaves, buds and shoots (Wingfield et al. 1996b). This pathogen was first discovered in Indonesia in 1996 and has subsequently been detected in Thailand, China, Vietnam and Timor (Wingfield et al. 1996b; Old et al. 2003a, 2003b; Burgess et al. 2006). $K$. eucalypti and $K$. epicoccoides are endemic to Australia and outbreaks have been noted in off-site plantations in the subtropics. For example, in northern NSW, K. eucalypti can cause severe damage to $E$. nitens plantations and $K$. epicoccoides can cause severe, repeated defoliation in $E$. grandis and E. grandis $\times$ E. camaldulensis plantations (Carnegie 2007b). $K$. eucalypti has also been introduced into New Zealand where it has resulted in the complete defoliation of juvenile leaves of E. nitens in New Zealand (Dick 1982). K. epicoccoides is known from many countries (Sankaran et al. 1995; Park et al. 2000) and generally causes disease on older leaves, although leaf blights have been observed in the tropics (B. Dell, pers. comm.).

During monitoring of eucalypt species trials in FNQ in July 2005, we observed leaves exhibiting symptoms similar to those observed for $K$. destructans. Samples were collected across several sites and preliminary examination revealed a fungus with a conidial morphology similar to that of $K$. destructans. This study describes the fungus as a new Kirramyces species from northern Qld and discusses its relationship to $K$. destructions. The origin of these species and the necessity for conducting surveillance and risk assessment are also considered.

\section{Materials and methods}

\section{Collection}

Eucalyptus leaves with symptoms resembling those of $K$. destructans were collected from a eucalypt species trial site situated $3 \mathrm{~km}$ north-west of Mareeba, near Cairns in FNQ. The trial was established in August 2004 to evaluate hardwood species grown using effluent irrigation in the dry tropics. Species planted in the trial included Corymbia spp., E. pellita, $E$. grandis and hybrids of $E$. grandis $\times E$. camaldulensis from South America. Collected leaves were wrapped in paper tissues, placed in paper bags, packed in tight-fitting plastic bags from which the air had been displaced to form a vacuum and stored in a fridge before the isolation of fungi.

\section{Fungal isolates}

Leaves were examined under a dissecting microscope, and conidia observed oozing from single pycnidia, were collected at the tip of a sterile needle. The conidia were transferred to malt extract $(20 \mathrm{~g} / \mathrm{L})$ agar (MEA) containing streptomycin at $150 \mu \mathrm{g} / \mathrm{mL}$ (Sigma-Aldrich, Sydney, Australia) in a single spot and allowed to hydrate for $2-4 \mathrm{~h}$. Under a dissecting microscope, conidia were then streaked across the surface of the medium using a sterile needle and single conidia were picked off the agar and transferred to new MEA plates. Cultures were grown at $20^{\circ} \mathrm{C}$ in the dark for 2 weeks and then transferred to fresh MEA plates. Cultures were maintained on 2\% MEA in tubes at $20^{\circ} \mathrm{C}$. Morphological characteristics of the isolates from this study were compared with those of other closely related species (Table 1). All isolates are maintained in the culture collection of the Forestry and Agricultural Biotechnology Institute, University of Pretoria, South Africa or at Murdoch University, Perth, Western Australia (MUCC). Ex-type cultures have been deposited in the collection of the Centraalbureau voor Schimmelcultures (CBS), Utrecht, the Netherlands. The holotype has been lodged in the herbarium of the Department of Primary Industries, Brisbane, Qld, Australia (BRIP). Isotype and paratype material is available from the Murdoch University herbarium (MURU).

\section{DNA extraction and PCR amplification}

The isolates were grown on $2 \% \mathrm{MEA}$ at $20^{\circ} \mathrm{C}$ for 4 weeks and the mycelium was harvested and placed in a $1.5-\mathrm{mL}$ sterile Eppendorf tube. Harvested mycelium was frozen in liquid nitrogen, ground to a fine powder and genomic DNA was extracted as described previously (Andjic et al. 2007a). The region spanning the second internal transcribed spacer (ITS) and part of $5.8 \mathrm{~S}$ region of the rDNA was amplified using the primers ITS-3 (5'GTA TCG ATG AAG AAC GCA GC $\left.3^{\prime}\right)$ and ITS-4 (5'TCC TCC GCT TAT TGA TAT GC $\left.3^{\prime}\right)$ White et al. (1990). Part of the $\beta$-tubulin $(\beta \mathrm{t})$ gene region was amplified with the primers $\beta \mathrm{t} 2 \mathrm{a}\left(5^{\prime} \mathrm{GGT}\right.$ AAC CAA ATC GGT GCT GCT TTC $3^{\prime}$ ) and $\beta \mathrm{t} 2 \mathrm{~b}\left(5^{\prime}\right.$ ACC CTC AGT GTA GTG ACC CTT GGC $3^{\prime}$ ) Glass and Donaldson (1995), part of translation elongation factor $1 \alpha(\mathrm{EF}-1 \alpha)$ gene with the primers EF1-728 (5'CAT CGA GAA GTT CGA GAA GG 3') and EF1-986R (5' TAC TTG AAG GAA CCC TTA CC 3') Carbone and Kohn (1999). The PCR reaction mixture, PCR conditions, the cleanup of products and sequencing were as described previously (Andjic et al. 2007a).

\section{Phylogenetic analysis}

In order to compare Kirramyces isolates used in this study with other closely related species, additional sequences were obtained from GenBank (Table 1). Sequence data were assembled using Sequence Navigator version 1.01 (Perkin Elmer) and aligned in Clustal X (Thompson et al. 1997). Manual adjustments were made visually by inserting gaps where necessary. All sequences derived in this study were deposited in GenBank and accession numbers are shown in Table 1.

Analyses were performed on individual datasets in phylogenetic analysis using parsimony (PAUP) version $4.0 \mathrm{~b} 10$ (Swofford 2003). The most parsimonious trees were obtained using heuristic searches with random stepwise addition in 100 replicates, with the tree bisection-reconnection branchswapping option on and the steepest-descent option, off. Maxtrees were unlimited, branches of zero length were collapsed and all multiple, equally parsimonious trees were saved. Estimated levels of homoplasy and phylogenetic signal (retention and consistency indices) were determined (Hillis and Huelsenbeck 1992). Branch and branch node support was determined using 1000 bootstrap replicates (Felsenstein 1985). Trees were rooted to Neofusicoccum ribis, which was treated as the outgroup taxon.

Bayesian analysis was conducted on the same aligned and combined dataset as the one used in the distance analysis. First, MrModelltest v. 3.5 (Nylander 2004) was used to determine the 


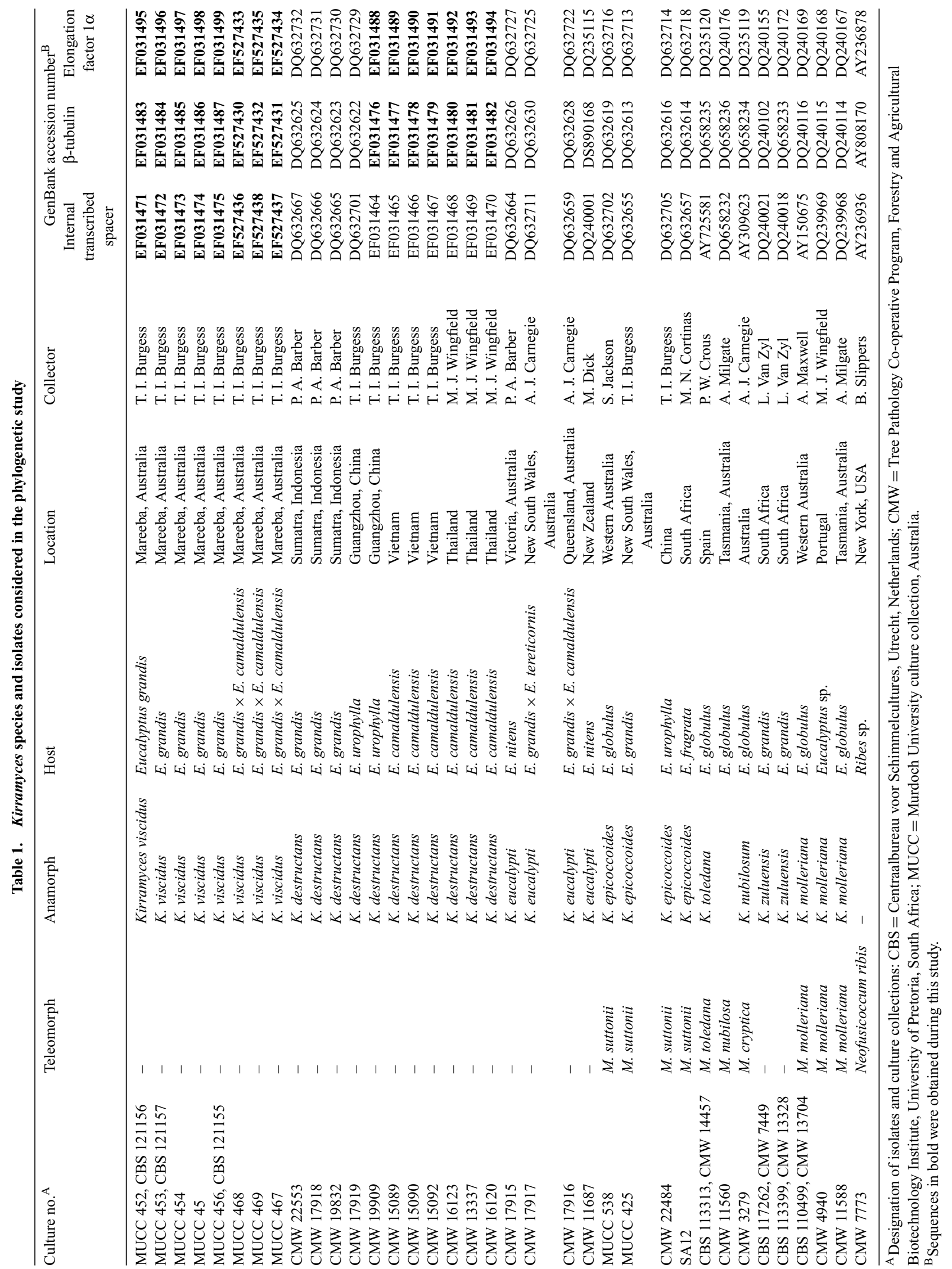


best nucleotide substitution model. Phylogenetic analyses were performed with MrBayes v. 3.1 (Ronquist and Heuelsenbeck 2003) applying a general time reversible substitution model with gamma and proportion of invariable site parameters to accommodate variable rates across sites. Two independent runs of Markov Chain Monte Carlo using 4 chains were run over 1000000 generations. Trees were saved every 1000 generations, resulting in 10001 trees. Burn-in was set at 50001 generations (i.e. 51 trees), well after the likelihood values converged to the stationary, leaving 9950 trees from which the consensus trees and posterior probabilities were calculated.

\section{Morphological characterisation}

In order to determine the taxonomic position of the Kirramyces species considered in this study, plugs (2-mm diameter) were cut from actively growing cultures and placed at the centres of Petri dishes $(55 \mathrm{~mm})$ containing one of three different nutrient media. Three replicates of each isolate (five isolates in total) were grown on $2 \%$ MEA, oatmeal agar (OMA) and sterilised eucalypt leaves placed on the surface of tap water agar (TWA) at 20 and $28^{\circ} \mathrm{C}$ in the dark. After 30 days, cultures were assessed for growth and photographed. Squash mounts of fruiting structures were prepared on slides in lacto-glycerol $(1: 1: 1$ volume of lactic acid, glycerol and water) and observed at $\times 1000$ magnification with an Olympus BH2 light microscope. The growth of cultures was determined by taking two measurements of colony diameter perpendicular to each other. Measurements of relevant taxonomic features used to distinguish between currently described Kirramyces spp. were made. Thus, each isolate was assessed for conidial size, shape, pigmentation and number of septa. Wherever possible, 30 measurements $(\times 1000$ magnification) of all taxonomically relevant structures were recorded for each species and the extremes are presented in parentheses. Colony colour was described using notations in the Munsell Soil Colour Charts (Gretag Macbeth, New Windsor, NY, revised 2000). Measurements of conidial size were obtained using the image analysis software Olysia BioReport 3.2 software imaging system. Data analyses were performed using descriptive statistics in Microsoft Excel.

\section{Results}

Distribution, impact and symptoms of Kirramyces sp.

The disease was first detected in August 2005 causing leaf blight to $E$. grandis and $E$. grandis $\times E$. camaldulensis hybrids at a single site in Mareeba, north Qld. Infection was limited to the lower canopy and no defoliation was observed. The site at Mareeba was revisited in August 2006 and defoliation levels of $95 \%$ and greater were noted on the $E$. grandis $\times$ E. camaldulensis hybrids (Fig. 1). New shoots were infected with both $K$. epicoccoides and the Kirramyces sp. considered in this study. $K$. epicoccoides was also detected on the leaves of $E$. grandis and E. pellita. While the hybrids were heavily infected with the Kirramyces sp., the damage on E. grandis of the Copperload provenance was limited to the lower canopy with less then $15 \%$ of foliage affected. Several other taxa trials in the region, which included $E$. grandis and $E$. grandis $\times E$. camaldulensis hybrids, were surveyed but the Kirramyces sp. found at Mareeba was not detected.

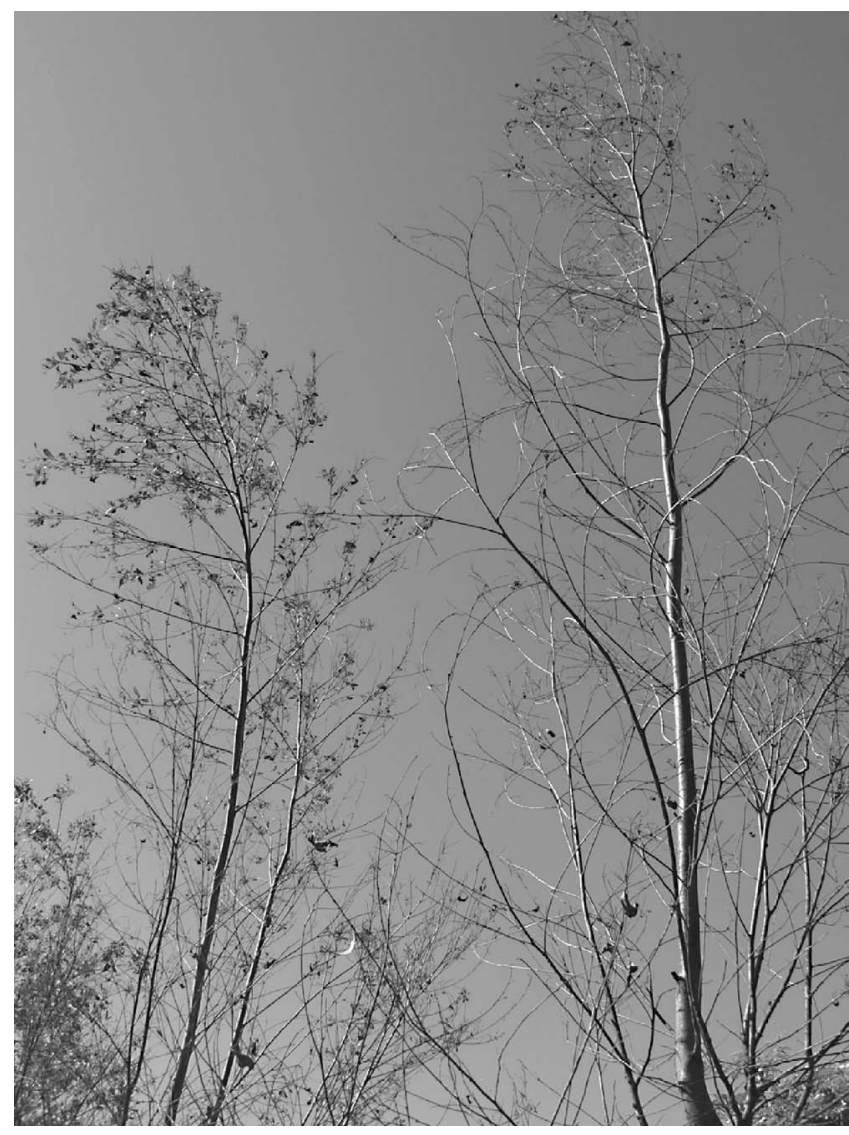

Fig. 1. Defoliated 15-month-old Eucalyptus grandis $\times$ E. camaldulensis at Mareeba, Atherton Tableland, Queensland, Australia. A year earlier the trees had full foliage and early symptoms of infection with Kirramyces viscidus.

Symptoms on leaves of E. grandis and $E$. grandis $\times E$. camaldulensis were very similar to those caused by $K$. destructans (Fig. $2 a, d$ ). Necrotic spots appeared on both sides of the leaves and were circular to irregular, 3-20 $\mathrm{mm}$ in diameter, single to confluent, medium brown to light brown with red brown borders on the adaxial surface, and a light brown colour on the abaxial surface. In some cases, young leaves were severely distorted. Conidia accumulated on the lower surface of the lesions giving rise to crusty black masses (Fig. 2c, $f$ ).

\section{DNA sequence comparisons}

The ITS2 dataset consisted of 203 characters, of which 51 were parsimony-informative and were used in the analysis. These data contained significant phylogenetic signal $[P<0.01$; phylogenetic signal $(\mathrm{gl})=-0.88]$. Heuristic searches of unweighted characters in PAUP resulted in a single most parsimonious tree of 106 steps [consistency index $(\mathrm{CI})=0.65$, retention index $(\mathrm{RI})=0.88$ ]. Bayesian analysis resulted in a tree with the same topology and clades as those revealed in the parsimony tree [Fig. 3a, TreeBASE (http://www.treebase.org/treebase/) = SN3318]. The EF- $1 \alpha$ dataset consisted of 337 characters, of which 156 were parsimony informative and were used in the analysis. 

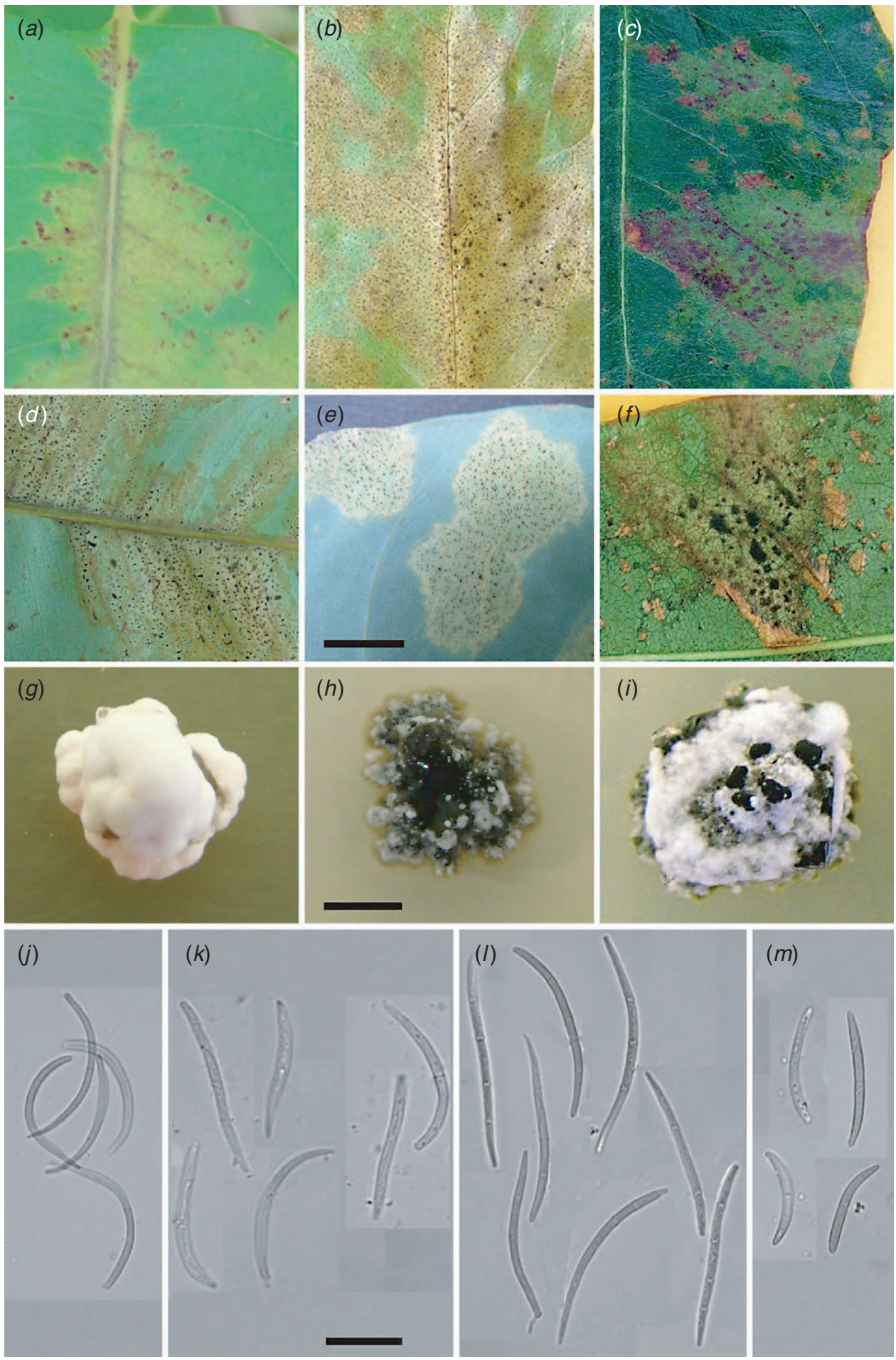

Fig. 2. A comparison between the foliar disease symptoms and cultural morphology of three Kirramyces spp. Symptoms of (a,d) K. destructans on leaves of Eucalyptus urophylla hybrids from Guangdong Province, China, $(b, e) K$. eucalypti on leaves of E. grandis, from Queensland, Australia and $(c, f) K$. viscidus sp. nov. on leaves of $E$. grandis from Mareeba, Queensland. Upper photo, adaxial surface; lower photo, abaxial surface. Bar $=10 \mathrm{~mm}$. Cultures on malt extract agar of $(g) K$. destructans isolate CMW 17918 (CMW = Tree Pathology Co-operative Program, Forestry and Agricultural Biotechnology Institute, University of Pretoria, South Africa), (h) K. eucalypti isolate MUCC 384 (MUCC = Murdoch University culture collection, Perth, Western Australia) and $(i)$ K. viscidus isolate CBS 121156 (CBS = Centraalbureau voor Schimmelcultures, Utrecht, Netherlands). Bar $=5 \mathrm{~mm}$. Conidia of $(j)$ K. destructans specimen PREM (PREM = South African National Mycological Herbarium) 59261, $(k)$ K. eucalypti specimen MURU 425 (MURU = Murdoch University herbarium) and $(l)$ K. viscidus specimen BRIP 49804 (BRIP = herbarium of the Department of Primary Industries, Brisbane, Queensland, Australia) and $(m)$ K. viscidus isolate CBS 121156. Bar $=15 \mu \mathrm{m}$. 

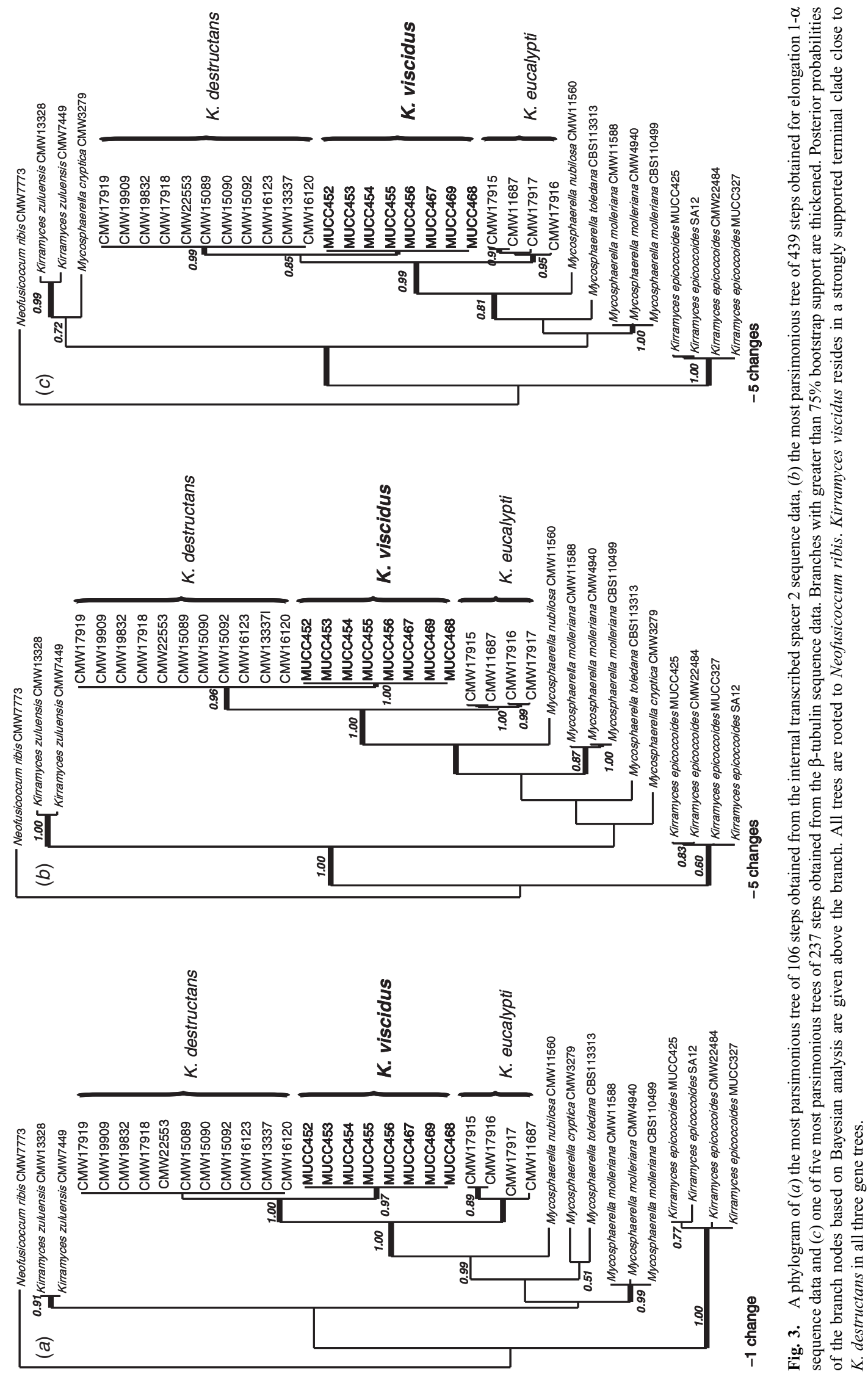
These data contained significant phylogenetic signal $(P<0.01$; $\mathrm{gl}=-0.93)$. Heuristic searches of unweighted characters in PAUP resulted in a single most parsimonious trees of 106 steps $(\mathrm{CI}=0.72, \mathrm{RI}=0.89)$. Bayesian analysis resulted in a tree with the same topology and clades as the parsimony tree (Fig. $3 b$, TreeBASE $=\mathrm{SN} 3318$ ). The $\beta \mathrm{t}$ dataset consisted of 384 characters, of which 90 were parsimony informative and were used in the analysis. These data contained significant phylogenetic signal $(P<0.01 ; \mathrm{gl}=-0.80)$. Heuristic searches of unweighted characters in PAUP resulted in a single most parsimonious tree of 106 steps $(\mathrm{CI}=0.72, \mathrm{RI}=0.88)$. Bayesian analysis resulted in a tree with the same topology and clades as the parsimony tree (Fig. 3c, TreeBASE $=\mathrm{SN} 3318$ ).

In all three analyses, the Kirramyces sp. from FNQ was closely related to, but phylogenetically distinct from $K$. destructans (Fig. 3). Isolates of both $K$. destructans and the Kirramyces sp. were monomorphic with no sequence variation observed for all isolates tested. Across the three gene regions sequenced, there were 12 fixed polymorphisms distinguishing $K$. destructans from the Kirramyces sp. (Table 2).

\section{Morphological characterisation}

At first appearance, the conidia of the Kirramyces sp. were very similar to those of $K$. destructans. The first difference noted between the Kirramyces sp. and $K$. destructans was the extremely hydrophobic and sticky spores and these required 2-4h of rehydration before the conidial masses could be teased apart. This is in contrast to $K$. destructans and $K$. eucalypti, where conidia are easily separated after rehydration for 1-5 min. The conidia of the Kirramyces sp. were very similar to those of
$K$. destructans and $K$. eucalypti in pigmentation, shape, size and number of septa (Fig. $2 j-m$ ).

Conidia of the new Kirramyces sp. were subhyaline to pale brown, $0-3$-septate and longer $(54 \mu \mathrm{m}$ on average, range $47-60 \mu \mathrm{m}$ ) than those of $K$. eucalypti (mean $43 \mu \mathrm{m}$, range 35-50 $\mathrm{m}$, which are also 0-3-septate) (Heather 1961; Walker et al. 1992; Andjic etal. 2007b). The conidia of the Kirramyces sp. were also longer than the conidia of specimens of $K$. destructans collected from China and Indonesia (mean $47 \mu \mathrm{m}$, range $38-55 \mu \mathrm{m}, 1-3$-septate) that were given by Andjic et al. (2007b) but slightly shorter $(50-65 \mu \mathrm{m}, 1-3$-septate) than conidia of specimen of $K$. destructans collected from Indonesia that were given by Wingfield et al. (1996b).

Pycnidia on leaf material collected at Mareeba were overmature and it was not possible to obtain measurements of conidiogenous cells from these specimens. New collections at the same location were made, but all trees were more then $95 \%$ defoliated and the remaining leaves were covered with $K$. epicoccoides mixed with over-mature pycnidia of the Kirramyces sp. Thus, the only description and measurements obtained from leaf specimens were those for the conidia. Consequently, pycnidia produced in culture were used to characterise the morphology of conidiogenous cells.

After 30 days of growth at $28^{\circ} \mathrm{C}$ in the dark on MEA, colonies of the Kirramyces sp. were $20-30 \mathrm{~mm}$ in diameter, the upper surface was white to pinkish white with sectors of light greenish grey and they were covered with pycnidia, the lower surface was pinkish grey to reddish brown with irregular margins (Fig. 2i). These characteristics are typical of both $K$. destructans and $K$. eucalypti (Crous 1998) (Fig. 2g-h). On OMA, colonies were

Table 2. Polymorphic nucleotides from sequence data of internal transcribed spacer (ITS), EF- $1 \alpha$ and $\beta$-tubulin gene regions showing the variation between isolates of Kirramyces destructans and Kirramyces sp. nov.

\begin{tabular}{|c|c|c|c|c|c|c|c|c|c|c|c|c|}
\hline \multirow{2}{*}{ Culture no. ${ }^{\mathrm{A}}$} & \multicolumn{3}{|c|}{ ITS } & \multicolumn{4}{|c|}{$\mathrm{EF}-1 \alpha$} & \multicolumn{5}{|c|}{$\beta$-tubulin } \\
\hline & 155 & 194 & 226 & 211 & 228 & 295 & 296 & 131 & 134 & 222 & 224 & 270 \\
\hline \multicolumn{13}{|c|}{ K. destructans } \\
\hline CMW17919 & G & $\mathrm{C}$ & $\mathrm{C}$ & $\mathrm{C}$ & $\mathrm{C}$ & - & - & $\mathrm{A}$ & G & $\mathrm{C}$ & $\mathrm{G}$ & $\mathrm{C}$ \\
\hline CMW19909 & G & $\mathrm{C}$ & $\mathrm{C}$ & $\mathrm{C}$ & $\mathrm{C}$ & - & - & A & G & $\mathrm{C}$ & G & $\mathrm{C}$ \\
\hline CMW17918 & G & $\mathrm{C}$ & $\mathrm{C}$ & $\mathrm{C}$ & $\mathrm{C}$ & - & - & $\mathrm{A}$ & G & $\mathrm{C}$ & $\mathrm{G}$ & $\mathrm{C}$ \\
\hline CMW22553 & $\mathrm{G}$ & $\mathrm{C}$ & $\mathrm{C}$ & $\mathrm{C}$ & $\mathrm{C}$ & - & - & $\mathrm{A}$ & G & $\mathrm{C}$ & G & $\mathrm{C}$ \\
\hline CMW19832 & $\mathrm{G}$ & $\mathrm{C}$ & $\mathrm{C}$ & $\mathrm{C}$ & $\mathrm{C}$ & - & - & A & G & $\mathrm{C}$ & G & $\mathrm{C}$ \\
\hline CMW15089 & G & $\mathrm{C}$ & $\mathrm{C}$ & $\mathrm{C}$ & $\mathrm{C}$ & - & - & A & $\mathrm{G}$ & $\mathrm{C}$ & $\mathrm{G}$ & $\mathrm{C}$ \\
\hline CMW15090 & G & $\mathrm{C}$ & $\mathrm{C}$ & $\mathrm{C}$ & $\mathrm{C}$ & - & - & $\mathrm{A}$ & G & $\mathrm{C}$ & G & $\mathrm{C}$ \\
\hline CMW15092 & $\mathrm{G}$ & $\mathrm{C}$ & $\mathrm{C}$ & $\mathrm{C}$ & $\mathrm{C}$ & - & - & $\mathrm{A}$ & $\mathrm{G}$ & $\mathrm{C}$ & $\mathrm{G}$ & $\mathrm{C}$ \\
\hline CMW16123 & G & $\mathrm{C}$ & $\mathrm{C}$ & $\mathrm{C}$ & $\mathrm{C}$ & - & - & $\mathrm{A}$ & $\mathrm{G}$ & $\mathrm{C}$ & $\mathrm{G}$ & $\mathrm{C}$ \\
\hline CMW13337 & $\mathrm{G}$ & $\mathrm{C}$ & $\mathrm{C}$ & $\mathrm{C}$ & $\mathrm{C}$ & - & - & $\mathrm{A}$ & G & $\mathrm{C}$ & G & $\mathrm{C}$ \\
\hline CMW16210 & G & $\mathrm{C}$ & $\mathrm{C}$ & $\mathrm{C}$ & $\mathrm{C}$ & - & - & A & G & $\mathrm{C}$ & G & $\mathrm{C}$ \\
\hline \multicolumn{13}{|c|}{ Kirramyces sp. nov. } \\
\hline MUCC452 & $\mathrm{T}$ & $\mathrm{T}$ & $\mathrm{T}$ & $\mathrm{T}$ & A & $\mathrm{T}$ & G & G & A & $\mathrm{T}$ & A & $\mathrm{T}$ \\
\hline MUCC453 & $\mathrm{T}$ & $\mathrm{T}$ & $\mathrm{T}$ & $\mathrm{T}$ & A & $\mathrm{T}$ & G & G & $\mathrm{A}$ & $\mathrm{T}$ & A & $\mathrm{T}$ \\
\hline MUCC454 & $\mathrm{T}$ & $\mathrm{T}$ & $\mathrm{T}$ & $\mathrm{T}$ & A & $\mathrm{T}$ & G & $\mathrm{G}$ & A & $\mathrm{T}$ & A & $\mathrm{T}$ \\
\hline MUCC455 & $\mathrm{T}$ & $\mathrm{T}$ & $\mathrm{T}$ & $\mathrm{T}$ & A & $\mathrm{T}$ & G & G & A & $\mathrm{T}$ & A & $\mathrm{T}$ \\
\hline MUCC456 & $\mathrm{T}$ & $\mathrm{T}$ & $\mathrm{T}$ & $\mathrm{T}$ & A & $\mathrm{T}$ & G & G & A & $\mathrm{T}$ & A & $\mathrm{T}$ \\
\hline MUCC468 & $\mathrm{T}$ & $\mathrm{T}$ & $\mathrm{T}$ & $\mathrm{T}$ & A & $\mathrm{T}$ & G & $\mathrm{G}$ & A & $\mathrm{T}$ & A & $\mathrm{T}$ \\
\hline MUCC469 & $\mathrm{T}$ & $\mathrm{T}$ & $\mathrm{T}$ & $\mathrm{T}$ & A & $\mathrm{T}$ & G & $\mathrm{G}$ & $\mathrm{A}$ & $\mathrm{T}$ & A & $\mathrm{T}$ \\
\hline MUCC470 & $\mathrm{T}$ & $\mathrm{T}$ & $\mathrm{T}$ & $\mathrm{T}$ & A & $\mathrm{T}$ & $\mathrm{G}$ & G & A & $\mathrm{T}$ & A & $\mathrm{T}$ \\
\hline
\end{tabular}

${ }^{A}$ Designation of isolates and culture collections: $\mathrm{CMW}=$ Tree Pathology Co-operative Program, Forestry and Agricultural Biotechnology Institute, University of Pretoria, South Africa; MUCC = Murdoch University culture collection, Australia. 
20-29 $\mathrm{mm}$ in diameter, pinkish white on the upper surface, and pink to dark olive grey with a regular margin on the reverse side. On TWA, colonies grew $18-28 \mathrm{~mm}$ in diameter, white to pink on the upper surface with sectors of reddish brown, and olive grey below with a regular margin. Some colonies produced pycnidia on their surfaces. Growth was slower at $20^{\circ} \mathrm{C}$ on all three media, though the colour and shape on each was similar. Conidia from culture were shorter $(33-45 \mu \mathrm{m})$ than conidia measured from leaf material $(47-60 \mu \mathrm{m})$. This is also true for $K$. eucalypti where conidia produced in culture were shorter $(24-32 \mu \mathrm{m})$ than conidia produced on leaf material $(35-50 \mu \mathrm{m})$ (Andjic et al. 2007b). Of the five isolates used in this study, only one produced pycnidia and conidiogenous cells in culture, on MEA at $28^{\circ} \mathrm{C}$.

\section{Taxonomy}

Phylogenetic inference, and to a lesser extent morphological characteristics, have provided robust evidence that the Kirramyces sp. causing a serious leaf disease on hybrids of E. grandis $\times E$. camaldulensis at Mareeba represents a unique taxon. The fungus is described here as a new species:

Kirramyces viscidus Andjic, P.A. Barber, T.I. Burgess sp. nov. (Fig. 4)

Mycobank no. MB 510859.

Teleomorph: Mycosphaerella sp. (based on phylogenetic inferences, but not seen).

Etymology: Name refers to the hydrophobic and exceptionally sticky conidia of the fungus.

Conidiomata pycnidialia hypophylla, solitaria, atrobrunnea ad atra. Conidia solitaria, 0-3-septata, subhyalina et pallide brunnea, parum verruculosa, cylindracea, recta ad diverse curvata, parietibus crassis, ad basim truncata, margine interdum fimbriato, apice obtuso, (30.5-)47-60(-78.5) $\times$ (2-)2.5-3.5(4.0-) $\mu \mathrm{m}$.

Leaf spots: circular to irregular, $3-20 \mathrm{~mm}$ in diameter, single to confluent, medium brown to light brown with red brown border on the top surface, light brown at the bottom. Conidiomata: pycnidial, hypophyllous, single, dark brown to black. Conidiophores reduced to conidiogenous cells. Conidia: solitary, 0-3-septate, subhyaline to pale brown, slightly verruculose, cylindrical, straight to variously curved, thickwalled, base truncate sometimes with marginal frill, apex obtuse, $(30.5-) 47-60(-78.5) \times(2-) 2.5-3.5(4.0-)($ mean $=54 \times 3 \mu \mathrm{m})$.

Cultures: Colonies $29 \mathrm{~mm}$ in diameter after 1 month at $28^{\circ} \mathrm{C}$ in the dark on MEA, white 5Yellow-Red (YR) $8 / 1$ to pink 5 YR $8 / 4$ on the upper surface, olive grey $5 \mathrm{YR} 7 / 1$ on reverse. Mycelium: Subhyaline to pale brown, septate, branched. Conidiomata pycnidial, single, dark brown to black, globose to subglobose, unilocular: wall of Textura angularis. Conidiogenous cells: doliiform to subcylindrical, smooth to slightly verruculose, aseptate to 1-septate, (5.5-)8-10.5 $(-12.5) \times(3-) 4.5-8(-9.0) \quad($ mean $=6.4 \times 9.5) \mu \mathrm{m}$, subhyaline to pale brown, proliferating enteroblastically, 1-2 times percurrently. Conidia: solitary, 0-1-septate, subhyaline to pale brown, smooth to slightly verruculose, cylindrical, straight to variously curved $(29-) 35-40(-47.5) \times(2.0-) 2.5-3.5(-4.0)$ $($ mean $=37 \times 3.0 \mu \mathrm{m})$, lateral branches present as secondary (b)

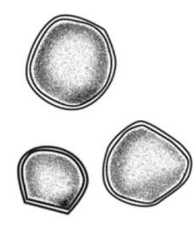

(a)

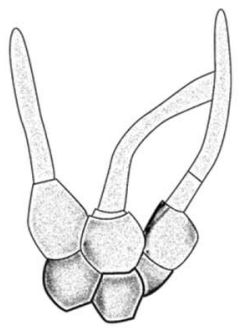

(c)

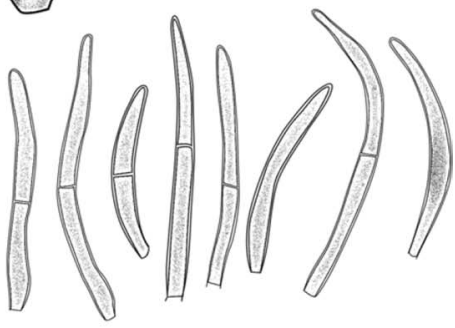

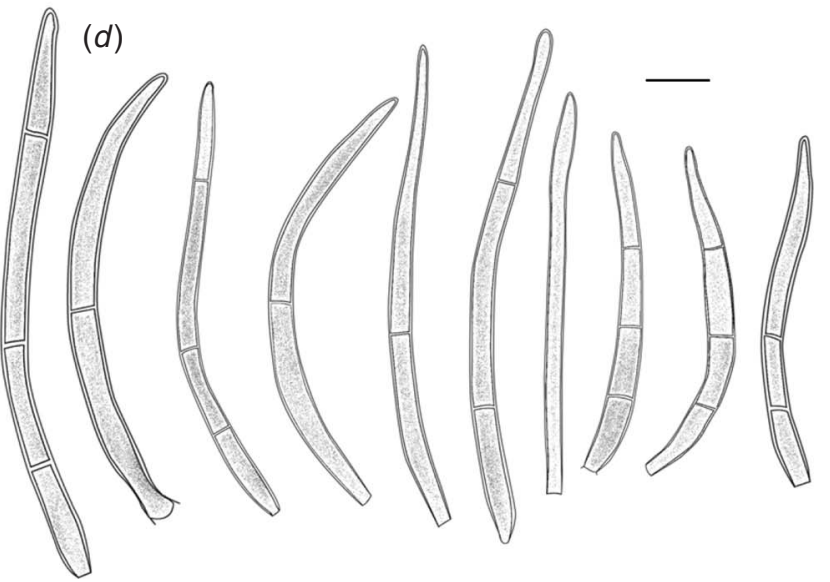

Fig. 4. Kirramyces viscidus (a) conidiogenous cells, (b) mycelium in culture producing chlamydospore-like synanamorph, $(c)$ conidia produced on malt extract agar and $(d)$ conidia produced in vivo. Scale bar $=10 \mu \mathrm{m}$.

conidia, mycelium in culture produce a synanamorph resembling chlamydospores $(12.5 \times 11 \mu \mathrm{m})$ that are dark brown and thick walled.

Holotype: on leaves of E. grandis Hill ex Maiden, Mareeba, Qld, Australia, T.I. Burgess, G.E.St.J Hardy, A.J. Carnegie, G. Pegg, August 2005, (HOLOTYPE BRIP 49804; culture ex-type CBS 121157).

Hosts: E. grandis, E. grandis $\times$ E. camaldulensis.

Geographic distribution: Mareeba, north Qld.

Additional specimens examined: K. viscidus on E. grandis, Mareeba, Qld, Australia, T.I. Burgess, G.E.St.J Hardy, A.J. Carnegie, G. Pegg, August 2005, (MURU427; culture ex-isotypes, CBS 121155, CBS 121156, MUCC 454, MUCC 455) and E. grandis $\times$ E. camaldulensis, (MURU431; culture ex-paratypes, MUCC 467, MUCC 468, MUCC 469).

Notes: $K$. viscidus can be distinguished from $K$. destructans and $K$. eucalypti by the production of highly hydrophobic and viscous spore masses. In vivo, $K$. viscidus produces longer conidia $(47-60 \mu \mathrm{m})$ than those of $K$. eucalypti $(35-50 \mu \mathrm{m})$. In contrast to $K$. destructans, whose conidia are 1-3-septate, the conidia of $K$. viscidus are $0-3$-septate. Unlike $K$. destructans, $K$. viscidus produces a synanamorph with chlamydospore-like structures in culture. The conidia of $K$. viscidus produced in vitro 
were shorter $35-40,($ mean $=37 \times 2.8 \mu \mathrm{m})$ than those produced in vivo $47-60,($ mean $=54 \times 3 \mu \mathrm{m})($ Fig. $2 \mathrm{~m})$.

\section{Discussion}

Comparisons of DNA sequence data revealed that the Kirramyces sp. collected from leaves of $E$. grandis and the hybrid of $E$. grandis $\times E$. camaldulensis from Mareeba represents a new taxon. This fungus has been named $K$. viscidus, a name emphasising the stickiness of its conidia. Based on phylogenetic analyses of sequence data obtained for the ITS, EF- $1 \alpha$ and $\beta$ t gene regions, $K$. viscidus has 12 polymorphic sites, which distinguish it from the closely related $K$. destructans. Based on morphological characteristics, K. viscidus can be distinguished from $K$. destructans by its remarkably sticky and hydrophobic conidia and the number of septa in the conidia. This report represents the first record of a new Kirramyces species very closely related to the destructive leaf blight and shoot pathogen, $K$. destructans. The latter fungus is considered a serious threat to the biosecurity of native eucalypts (Burgess et al. 2006) but has not been detected in Australia. The presence of a very similar but different fungus in the country will necessitate very careful comparisons when new records of similar Kirramyces spp. are made.

Sequence comparisons for all the isolates of $K$. viscidus examined in this study were identical. Conidial measurements for specimens on leaves also revealed no obvious differences between different collections. Kirramyces spp. from eucalypts are morphologically similar and thus difficult to distinguish from each other. Their current taxonomy consequently relies more heavily on DNA sequence comparisons than on morphology (Andjic et al. 2007a, 2007b).

The eucalypt taxa trial where $K$. viscidus was discovered was established in an ex-pasture area near remnant vegetation. In this trial, the $E$. grandis $\times$ camaldulensis hybrids from South America are highly susceptible to infection by $K$. viscidus, while endemic Eucalyptus spp. are less susceptible. These hybrids, a range of clones initially tested in the late 1990s, have also shown high susceptibility to K. epicoccoides in NSW (Carnegie 2007a, $2007 b$ ) and to K. eucalypti in southern Qld (G. S. Pegg, pers. obs.). Therefore, they would not be suitable for planting in FNQ. This is not surprising, as these hybrids were specifically selected for planting in South America; an area free of most Australian native pests and diseases to which they may be susceptible. E. grandis, selected from seed derived from the Copperload provenance near Cairns in north Qld, was less susceptible to infection by $K$. viscidus, with only $15 \%$ of the foliage affected. $K$. viscidus was not detected on E. pellita and Corymbia spp., which was also planted in the trial. Based on these findings, $K$. viscidus is most probably endemic to Australia and would be unlikely to cause serious diseases on endemic Eucalyptus spp. The most likely source of the pathogen is the remnant vegetation close to the trial site.

The close relativity of $K$. viscidus to the aggressive pathogen $K$. destructans and the similarity in disease symptoms, suggests that the pathogen could seriously damage Australian eucalypt plantations in the future. There is an urgent need to study the biology and ecology of $K$. viscidus and to determine its potential impact to the eucalypt industry. Thus, surveys to find possible hosts in both native forests and plantations need to be conducted in tropical regions, where non-endemic eucalypt plantations are being established. Here, priority should be given to native stands of $E$. grandis to target potential resistance for breeding programs using Australian derived material.

\section{Acknowledgements}

This work was funded in part by the Australian Research Council DP0343600, 'Population genetics of fungal pathogens that threaten the biosecurity of Australia's eucalypts'. V. Andjic received a Murdoch University Doctoral Research Scholarship to undertake this study and related studies. We also thank Alex George for editing the Latin description and Dianne White for technical assistance.

\section{References}

Andjic V, Hardy GEStJ, Cortinas MN, Wingfield MJ, Burgess TI (2007a) Multiple gene genealogies reveal important relationships between Phaeophleospora spp. infecting Eucalyptus leaves. FEMS Microbiology Letters 268, 22-33. doi: 10.1111/j.1574-6968.2007.00637.x

Andjic V, Barber PA, Carnegie AJ, Hardy GEStJ, Wingfield MJ, Burgess TI (2007b) Phylogenetic reassessment supports accommodation of Phaeophleospora and Colletogloeopsis from eucalypts in Kirramyces. Mycological Research, in press.

Barber PA (2004) Forest Pathology: the threat of disease to plantation forests in Indonesia. The Plant Pathology Journal 3, 97-104.

Burgess TI, Andjic V, Hardy GEStJ, Dell B, Xu D (2006) First report of Phaeophleospora destructans in China. Journal of Tropical Forest Science 18, 144-146.

Carbone I, Kohn LM (1999) A method for designing primer sets for speciation studies in filamentous ascomycetes. Mycologia 91, 553-556. doi: $10.2307 / 3761358$

Carnegie AJ (2007a) Forest health condition in New South Wales, Australia, 1996-2005. I. Fungi recorded from eucalypt plantations during forest health surveys. Australasian Plant Pathology 36, 213-224. doi: 10.1071/AP07020

Carnegie AJ (2007b) Forest health condition in New South Wales, Australia, 1996-2005. II. Fungal damage recorded in eucalypt plantations during forest health surveys and their management. Australasian Plant Pathology 36, 225-239. doi: 10.1071/AP07021

Carnegie AJ, Stone C, Lawson SA, Matsuki M (2005) Can we grow certified eucalypt plantations in subtropical Australia? - An insect pest management perspective. New Zealand Journal of Forestry Science 35, 223-245.

Cortinas MN, Koch N, Thain J, Wingfield BD, Wingfield MJ (2004) First record of the Eucalyptus stem canker pathogen, Coniothyrium zuluense from Hawaii. Australasian Plant Pathology 33, 309-312. doi: 10.1071/AP04015

Cortinas MN, Burgess TI, Dell B, Xu DP, Crous PW, Wingfield BD, Wingfield MJ (2006) First record of Colletogloeopsis zuluense comb. nov., causing a stem canker of Eucalyptus in China. Mycological Research 110, 229-236. doi: 10.1016/j.mycres.2005.08.012

Crous PW (1998) Mycosphaerella spp. and their anamorphs associated with leaf spot diseases of Eucalyptus. Mycologia Memoir 21, 1-170.

Dick M (1982) Leaf-inhabiting fungi of eucalypts in New Zealand. New Zealand Journal of Forestry Science 12, 525-537.

Dickinson G, Bristow M, Kelly N (2004) Promising high value hardwood plantation tree species for the dry tropics of Queensland. In 'Prospects for high-value hardwood timber plantations in the 'dry' tropics of northern Australia. Proceedings of a workshop held in Mareeba, Queensland, 19-21 October 2004'. (Eds DI Bevage, M Bristow, DG Nikles, D Skelton) (CD-ROM) (Private Forestry North Queensland Association Inc.: Kairi)

Felsenstein J (1985) Confidence intervals on phylogenetics: an approach using bootstrap. Evolution 39, 783-791. 
Gezahgne ARJ, Thu PQ, Wingfield MJ (2003) Coniothyrium stem canker of Eucalyptus, new to Argentina and Vietnam. South African Journal of Science 99, 587-588.

Gezahgne ACM, Wingfield MJ, Roux J (2005) Characterisation of the Coniothyrium stem canker pathogen on Eucalyptus camaldulensis in Ethiopia. Australasian Plant Pathology 34, 85-90. doi: 10.1071/AP04079

Glass NL, Donaldson GC (1995) Development of primer sets designated for use with the PCR to amplify conserved regions from filamentous Ascomycetes. Applied and Environmental Microbiology 61, 1323-1330.

Heather WA (1961) Studies on Septoria sp. nov. causing a leaf blotch disease of Eucalyptus dalrympleana Maiden. MSc Thesis, University of Sydney.

Hillis DM, Huelsenbeck JP (1992) Signal, noise and reliability in molecular phylogenetic analysis. The Journal of Heredity 83, 189-195.

Lee JD (2007) Achievements in forest tree genetic improvement in Australia and New Zealand 2: development of Corymbia species and hybrids for plantations in eastern Australia. Australian Forestry 70, 11.

National Forestry Inventory (2004) 'National plantation inventory update March 2004.' (Bureau of Rural Sciences: Canberra)

Nylander JAA (2004) MrModeltest v2. Program distributed by the author. Evolutionary Biology Centre, Uppsala University.

Old KM, Pongpanich K, Thu PQ, Wingfield MJ, Yuan ZQ (2003a) Phaeophleospora destructans causing leaf blight epidemics in SouthEast Asia. In 'ICPP. Christchurch, New Zealand'. p. 165.

Old KM, Wingfield MJ, Yuan ZQ (2003b) 'A manual of diseases of eucalypts in South-East Asia.' (Centre for International Forestry Research: Bogor, Indonesia)

Park RF, Keane PJ, Wingfield MJ, Crous PW (2000) Fungal diseases of eucalypt foliage. In 'Diseases and pathogens of eucalypts'. (Eds PJ Keane, GA Kile, FD Podger, BN Brown) pp. 153-240 (CSIRO Publishing: Melbourne)
Ronquist F, Heuelsenbeck JP (2003) MrBayes 3: Bayesian phylogenetic inference under mixed models. Bioinformatics (Oxford, England) 19, 1572-1574. doi: 10.1093/bioinformatics/btg180

Sankaran KC, Sutton BC, Minter DW (1995) A checklist of fungi recorded on eucalypts. Mycological Papers 170, 1-375.

Swofford DL (2003) 'Phylogenetic analysis using parsimony (*and other methods).' Version 4. (Sinauer Associates: Sunderland, MA)

Thompson JD, Gibson TJ, Plewniak F, Jeanmougin F, Higgins DG (1997) The ClustalX windows interface: flexible strategies for multiple sequence alignment aided by quality analysis tools. Nucleic Acids Research 24, 4876-4882.

Turnbull JW (2000) Economic and social importance of eucalypts. In 'Diseases and pathogens of eucalypts'. (Eds PJ Keane, GA Kile, FD Podger, BN Brown) pp. 1-10. (CSIRO Publishing: Melbourne)

Walker J, Sutton BC, Pascoe IG (1992) Phaeoseptoria eucalypti and similar fungi on Eucalyptus with description of Kirramyces genom. nov. (Coelomycetes). Mycological Research 96, 911-924.

White TJ, Bruns T, Lee S, Taylor J (1990) Amplification and direct sequencing of fungal ribosomal RNA genes for phylogenetics. In 'PCR Protocols: a guide to methods and applications'. (Eds MA Innes, DH Gelfand, JJ Sninsky, TJ White) pp. 315-322. (Academic Press: San Diego, CA)

Wingfield MJ, Crous PW, Couthinho TA (1996a) A serious new canker disease of Eucalyptus in South Africa caused by a new species of Coniothyrium. Mycopathologia 136, 139-145. doi: 10.1007/ BF00438919

Wingfield MJ, Crous PW, Boden D (1996b) Kirramyces destructans sp. nov., a serious leaf pathogen of Eucalyptus in Indonesia. South African Journal of Botany 62, 325-327.

Manuscript received 1 June 2007, accepted 30 June 2007 